\title{
Comparison of two adrenergic beta-receptor blocking agents, alprenolol and propranolol, in treatment of angina pectoris
}

\author{
D. J. Hetherington, M. B. Comerford, G. Nyberg, ${ }^{1}$ and E. M. M. Besterman \\ From the Department of Cardiology, St. Mary's Hospital, London
}

Twenty-six patients with typical angina pectoris were treated with alternating four-week courses of alprenolol $400 \mathrm{mg}$ daily, propranolol $160 \mathrm{mg}$ daily, and placebo for 12 months (standard dose regimen). Subsequently, I7 of the patients took part in a 6-month dose-response study in which the dose was increased by one and a half and two times the standard dose. All patients were given digitalis throughout except for 8 in the dose response study.

Statistically significant increases in the total work performed on a bicycle ergometer were found with both active compounds when compared with placebo, the increases being around Io per cent on standard dose, and between 35 and 47 per cent in the dose response study. No obvious influence of digoxin on exercise tolerance was found.

Patients with previous myocardial infarction responded better at standard dose levels, and also sustained an improved exercise tolerance on placebo, when compared with those who had not had an infarct.

Both compounds reduced the heart rate and blood pressure at rest and after exercise. Triple product values (product of heart rate, systolic pressure, and QT time) were decreased on both drugs in comparison with placebo, both at rest and at the end of effort, by 15 to 20 per cent. At the higher dose levels, the "normalization' times of the systolic blood pressure after work were slower with propranolol than with alprenolol.

Aspects of the clinical trial investigation in angina pectoris patients are discussed, including the problems of digitalization during long-term treatment with beta-blockers.

There was no difference in the cardiac depressant effects between the two drugs. With the exception of 4 patients, side effects were slight.

Adrenergic beta-receptor blocking compounds have been used for some time in the treatment of angina pectoris. The available beta-blockers differ in certain ways, and there has been much discussion as to how this might influence their effectiveness. It has, for instance, been suggested that a beta-blocker having some intrinsic beta-receptor stimulating effect, such as alprenolol, might be less prone to cause cardiac failure than a drug without such an effect, such as propranolol. However, the suggestion has also been made that the latter type of beta-blocker could be more efficacious owing to a higher degree of inhibition of chronotrophic stimuli. Furthermore, studies of prophylactic treatment with beta-blockers in angina have usually been of a short-term charac-

Received 15 September 1972.

${ }^{1}$ Present address: Medical Service, I, Sahlgrenska Hospital, Gothen burg, Sweden. ter. The purpose of the present study was to make a long-term comparison of these two beta-blockers in order to elucidate these points.

Obtaining a patient population for the evaluation of newly introduced beta-receptor blocking agents in the treatment of angina pectoris is complicated by previously established and satisfactory therapy with analogous compounds in many patients.

Accurate assessment of the response of angina to treatment is also made difficult by the effects of the normal fluctuation of the disease, often related to climatic and emotional changes.

It is also becoming increasingly difficult in hospital practice to find patients with 'steady state' angina suffering from one to two attacks a day or more, such patients being considered most suitable for these types of study. Proper readjustment of the patient's daily routine, together with the free use of 
prophylactic glyceryl trinitrate, is usually responsible for this reduced frequency of attacks.

In view of these problems, it proved necessary to draw on patients from four departments of cardiology in London. This report presents the results of such a study in patients treated with alternating monthly courses of alprenolol, propranolol, and placebo for a period of at least 12 months at the usual dose level recommended in current clinical practice. In view of the long-term nature of the study, it was decided that all patients would receive digoxin $0.25 \mathrm{mg}$ daily. At the end of this period of treatment, a dose response study was performed at two additional therapeutic levels of each compound, including the omission of digoxin in certain selected patients.

The dose levels chosen for the two beta-blockers have been found to be equipotent with regard to inhibition of isoprenaline-induced and exerciseinduced tachycardia in man (Åblad et al., 1967; Kaltenbach et al., 1971).

\section{Patients and methods}

Patients with angina were very critically selected and at whichever of the four cardiac departments they attended, were seen and examined by the same physician (D.J.H.), except when she was away on annual holidays when another of us (M.B.C.) maintained the continuity. Patients were chosen whose anginal symptoms had been in an unchanged state for a minimum of 3 months, and who were complaining of a minimum of 5 attacks a week.

Factors in selection included the ability of the patient to leave employment for regular hospital attendance, emotional stability, and competence as a good witness. Patients suffering from asthma or other respiratory disease, anaemia, aortic stenosis, or intermittent claudication were excluded.

Of the 26 patients, 1o continued with previous treatment (diuretics, anticoagulants, tranquillizers) during the study. Glyceryl trinitrate was taken freely for the anginal attacks, and in some cases prophylactically as well if this had been their previous practice, in which case separate recordings on diary cards were made by the patient.

A simple record card was completed by the patient and returned to the hospital at each visit, showing the number of prophylactic and therapeutic glyceryl trinitrate tablets taken each day, the number of daily anginal attacks, and any possible precipitating factors such as sudden weather change or emotional crises.

The degree of angina in each patient was assessed according to one of six grades:

I) Angina on strenuous effort only.

2) Angina on walking at normal speeds for over half a mile.

3) Angina on walking at normal speeds for less than half a mile.
4) Angina on slow walking for a short distance.

5) Angina on slight effort and occasionally at rest.

6) Frequent angina at rest.

At each visit, conditions were standardized as far as possible in terms of appointment time, intake of tablet to examination time (usually $I$ to 2 hours), time of previous light meal, and a 30-minute rest period before examination.

Using a mechanically braked Monark bicycle ergometer (Varberg, Sweden), exercise tests were carried out at every visit using a standard procedure of 4 minutes at each load of 300,600 , and $900 \mathrm{kpm} / \mathrm{min}$ until the onset of anginal pain. During the course of the study, it was noted that in some patients, a slower increment stepwise seemed more desirable (i.e. $300,450,600 \mathrm{kpm} / \mathrm{min}$ ) as cessation of exercise took place immediately after an increase in load. A basic metronome speed of 100 a minute was used.

Total work performed during the exercise test was calculated by multiplying load by time, i.e. $300 \mathrm{kpm} / \mathrm{min}$ for 4 minutes $=1200 \mathrm{kpm}$.

It was stressed to each patient that the pain end-point should be no more than that experienced under otherwise 'normal' conditions, e.g. walking up an incline, which would force them to stop.

In some cases, dyspnoea rather than pain determined the end-point during exercise, but the same criteria as above still held. In such cases, the dyspnoea end-point had been evident from the start of the study.

At each exercise test, a note was made on the specially designed clinical record sheet of the exact reason for discontinuing exercise, the time of onset of pain, and the exact duration of pain. Heart rate and blood pressure recordings were taken at rest, at the end of each step of exercise, and at 2, 4, and 6-minute intervals during the post-exercise phase.

Electrocardiograms were recorded from all leads before and after exercise, and a left praecordial recording was made during the last 15 seconds of each phase of exercise, and during the post-exercise period. To facilitate a better quality recording, the reference electrode to the left leg was sited on the forehead, and the right leg to the right arm.

Recordings of the room temperature, external temperature, and the patient's weight were made at each visit. Care was also taken to ensure that the time interval between tablet intake and the start of the exercise test remained at about I hour.

Electrocardiographic abnormalities during the exercise test were assessed on the change in the QT ratio based on Bazett's formula (Bazett, 1920), it being accepted that digitalis precluded significant interpretation of the ST segment depression. Thus, measurements of the QT ratio were recorded at rest, on stopping exercise, and at 2, 4, and 6-minute intervals after stopping exercise, the latter recordings being made while the patient was still sitting on the bicycle.

At every visit, a blood sample was taken for the estimation of the serum level of alprenolol, carried out by gasliquid chromatography (Ervik, 1969). Periodic screening investigations including haemoglobin, white cell count, 
blood urea, and liver function tests were carried out during the study.

Two separate studies were undertaken during this trial, the initial standard dose study, followed by the dose response study.

\section{Standard dose study}

There was an initial run-in period of 8 weeks during which all patients received placebo tablets one q.i.d., and a full medical assessment including exercise tolerance every 2 weeks. In a few cases previously on propranolol, a deterioration of the anginal state occurred, thus necessitating their exclusion from this study, and therefore excluding patients in whom benefit would have been most evident.

Subsequently, patients received 4 weeks of alternating treatment in a double-blind random crossover manner of alprenolol $100 \mathrm{mg}$ q.i.d., propranolol $40 \mathrm{mg}$ q.i.d., i.e. the standard dose regimen, and placebo tablet one q.i.d., the tablets being identical in shape, colour, size, and taste. To avoid the onset of side effects, it was recommended that every 4-week course should start at a dose of half a tablet q.i.d. for the first 7 days, followed by one tablet q.i.d. for the remaining $2 \mathrm{I}$ days.

Patients were advised that an evaluation was being carried out on 3 different drugs that had been used in the treatment of angina pectoris. All gave their consent.

In the statistical evaluation, Student's $t$ test for paired differences has been used, two-tailed, unless otherwise stated.

\section{Dose response study}

a) At the end of 12 months double-blind study using the standard dose regimen, all patients entered a dose response study where their exercise tolerance was assessed after three-week alternating courses of alprenolol and propranolol therapy at higher dose levels. The doses used were alprenolol $600 \mathrm{mg}$ daily and propranolol 240 $\mathrm{mg}$ daily, then alprenolol $800 \mathrm{mg}$ daily and propranolol $320 \mathrm{mg}$ daily (i.e. one and a half and twice the standard dose regimen). Once again, the study was double-blind in a random crossover manner, and patients remained on digoxin.

b) After these four courses of treatment, those patients who reported subjective improvement and had increased exercise tolerance then continued with the optimal effective dose of the beta blockers without digoxin therapy. However, of the 16 patients under study at this stage, only 8 satisfied the criteria for digoxin withdrawal based on the presence of a normal heart size on the chest $x$-ray, no evidence of pulmonary venous congestion, no previous history of a myocardial infarction or heart failure, and that pain and not dyspnoea was the endpoint of the exercise tolerance test.

These dose response studies took place on all patients during the period October 1970 to May 1971 .

\section{Results}

Although a total of 43 patients entered the study during the first 12 months starting September 1969, only 26 ( 20 men and 6 women) completed at least one 3-month period of treatment (Table I). Results of 73 treatment periods are assessed in Tables 2, 3, and 4. Eight patients defaulted for non-medical reasons during the run-in period, and a further 8 patients were withdrawn from the study when their clinical condition began to deteriorate during the first few days on placebo therapy, and it was considered essential for them to be on continued betablocker therapy. One further patient fell out due to side effects (headache) from digoxin administered during the run-in period.

\section{Exercise tolerance during run-in and placebo periods}

When looking at the total work in the four control tests and the subsequent placebo tests, it was apparent that, on average, the second, third, and fourth tests (on placebo) were about 20 per cent improved on the first test, but exercise tolerance then fell though still remained 8 per cent higher in the subsequent placebo tests.

As we had a significant number of patients who could be stratified into those with pain as the endpoint during exercise, and those with dyspnoea, and also into two groups depending on whether or not there was a previous history of myocardial infarction, it was felt that the results of exercise tolerance of these groups on placebo should be assessed. There was no significant difference between the pain and the dyspnoea groups. Patients with a previous myocardial infarction $(\mathrm{MI}+)$ seemed to sustain an improved exercise tolerance with placebo averages around 20 per cent higher than the first exercise test, in contrast to those with no previous history (MI - ) who, after the initial run-in improvement (as seen in the group as a whole), steadily decreased. This is also apparent in the Fig. where the total work has been averaged (with correction for missing values) for each quarter of the year. Initially, the results follow a similar trend until the end of the first 12 months, when the exercise tolerance of the MI - group continues to decrease, against the steady state of the MI + patients.

\section{Standard dose study}

Total work Analysis of each separate 3-month block showed no significant difference in total work for any drug compared to placebo. However, when the 3-month blocks were averaged for each patient, and the calculated mean values averaged, there was a statistically significant difference of $I I \cdot 4$ per cent increase of total work on alprenolol $(P<0 \cdot 01)$ and 9.3 per cent increase with propranolol $(P<0.05)$ (Table 2). In those patients who were changed from 
TABLE I Data for 26 patients included in study

\begin{tabular}{|c|c|c|c|c|c|c|}
\hline Case No. & Sex & $\begin{array}{l}\text { Age } \\
(y r)\end{array}$ & $\begin{array}{l}\text { Grade of } \\
\text { angina }\end{array}$ & $\begin{array}{l}\text { Duration of } \\
\text { angina } \\
\text { (mth) }\end{array}$ & $\begin{array}{l}\text { Other } \\
\text { therapy }\end{array}$ & $\begin{array}{l}\text { Myocardial } \\
\text { infarction }\end{array}$ \\
\hline I & $\mathbf{M}$ & 57 & 3 & 7 & & + \\
\hline 2 & $\mathbf{M}$ & 52 & 4 & 10 & D & + \\
\hline 3 & $\mathbf{M}$ & 51 & 4 & 5 & & + \\
\hline 4 & M & 56 & 2 & 3 & & - \\
\hline 5 & $M$ & 45 & 3 & 9 & & - \\
\hline 6 & $\mathbf{M}$ & 59 & 2 & 24 & $\mathrm{D}, \mathrm{A}$ & + \\
\hline 7 & $\mathrm{~F}$ & 65 & 3 & 36 & A & + \\
\hline 8 & $\mathbf{M}$ & 65 & 4 & 30 & & + \\
\hline 9 & $\mathbf{F}$ & $6 I$ & 2 & 12 & A & + \\
\hline 10 & $M$ & 53 & 3 & 12 & A & + \\
\hline II & $\mathbf{M}$ & 67 & 3 & 12 & & - \\
\hline 12 & $\mathbf{M}$ & 61 & 2 & 12 & & - \\
\hline 13 & $\mathbf{M}$ & 60 & 3 & 18 & D & + \\
\hline 14 & $\mathbf{M}$ & 49 & 4 & 24 & & - \\
\hline I5 & $\mathbf{M}$ & 54 & 4 & 48 & & - \\
\hline 16 & $\mathbf{M}$ & 59 & 3 & 24 & A & + \\
\hline 17 & $\mathbf{M}$ & 33 & I & 60 & & + \\
\hline 18 & $\mathbf{F}$ & 67 & 2 & 8 & & - \\
\hline 19 & $\mathbf{F}$ & 58 & 4 & 36 & $\mathbf{S}$ & + \\
\hline 20 & $\mathbf{M}$ & 44 & 2 & 60 & A & + \\
\hline 21 & $\mathbf{M}$ & 62 & 3 & 56 & & + \\
\hline 22 & $\mathrm{~F}$ & 62 & 4 & 18 & & - \\
\hline 23 & $\mathbf{M}$ & 69 & 3 & 48 & $\mathbf{S}$ & - \\
\hline 24 & $\mathbf{M}$ & 46 & 3 & 5 & D & + \\
\hline 25 & $\mathbf{M}$ & 54 & 3 & 3 & & - \\
\hline 26 & F & 49 & 2 & 24 & & - \\
\hline $\begin{array}{l}\text { Means } 20 M \\
\text { Range }\end{array}$ & $6 \mathrm{~F}$ & $\begin{array}{l}56 \cdot I \\
\pm I \cdot 7\end{array}$ & & $\begin{array}{l}23 \cdot 2 \\
3 \text { to } 60\end{array}$ & & $15+$ \\
\hline
\end{tabular}

$D$, diuretic; A, anticoagulant; $S$, sedative.

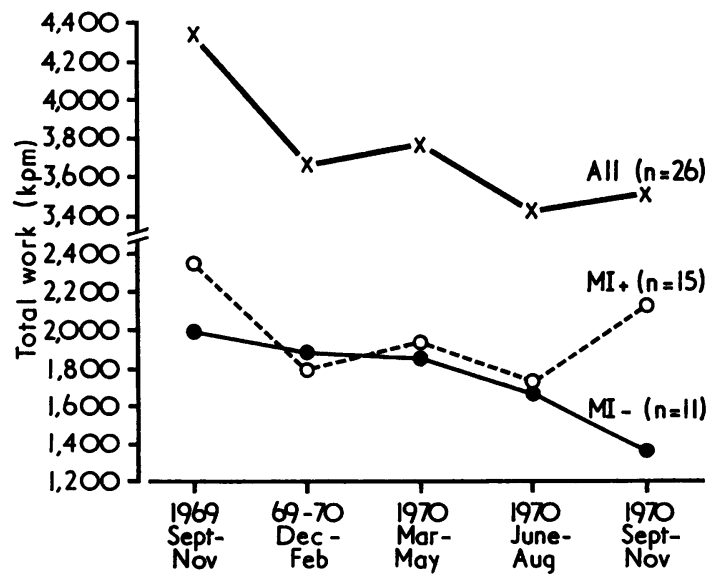

FIG. Total work at 'run-in' and placebo tests over I5 months (weighted means) for all patients, and divided into those with previous myocardial infarction $(M I+)$ and those without $(M I-)$. the $300,600,900 \mathrm{kpm} / \mathrm{min}$ protocol to the 300 , 450,600 protocol of exercise test during the study, there was no statistically significant difference between the total work performed with either protocol. In a few cases, it was not possible to make comparisons using the same protocol in a 3-month block. In the majority of such cases, the possible difference was so small as to be considered insignificant, as the total work was low (in fact identical up to 1200 $\mathrm{kpm}$ ) on both protocols. There were a few cases, however, where the difference in exercise protocol might have influenced the results significantly. In those cases, adjustments have been made, and always to the disadvantage of the beta-blockers.

When looking at the best average responses in total work, irrespective of the drug, it was seen that the patients were well divided into two groups. One group had a median value of 27 per cent (range from +16 to $+81 \%$, in 15 patients), while the other group of I I patients had a median value of 0 per cent (range of -23 to $+10 \%$ ). As the mean placebo results varied little with time, once the first run-in tests were done, we have considered the first group as 'responders' and the second group as the 'non- 
TABLE 2 Total work (kpm) performed by all patients on standard dose regimen: values are means of all completed 3-month periods of treatment ( ${ }^{\star}$ Responders)

\begin{tabular}{|c|c|c|c|c|c|}
\hline Case No. & $\begin{array}{l}\text { Alprenolol } \\
400 \text { mg daily }\end{array}$ & $\begin{array}{l}\% \text { change } \\
\text { from placebo }\end{array}$ & $\begin{array}{l}\text { Propranolol } \\
\text { I60 mg daily }\end{array}$ & $\begin{array}{l}\% \text { change } \\
\text { from placebo }\end{array}$ & Placebo \\
\hline I & 3400 & $8 I^{\star}$ & 2325 & $24^{\star}$ & 1875 \\
\hline 2 & 1667 & 14 & 1933 & $32^{\star}$ & 1467 \\
\hline 3 & 975 & $18^{\star}$ & 1050 & $27^{\star}$ & 825 \\
\hline 4 & 2900 & -9 & 3008 & -2 & 3067 \\
\hline 5 & 1200 & -43 & 1650 & -23 & 2125 \\
\hline 6 & 3000 & $17^{\star}$ & 2950 & $15^{\star}$ & 2563 \\
\hline 7 & 1500 & 0 & 1200 & -25 & 1500 \\
\hline 8 & 2100 & $35^{\star}$ & 1500 & -3 & 1550 \\
\hline 9 & 1269 & 4 & I 594 & $31^{\star}$ & 1219 \\
\hline 10 & 1050 & $27^{\star}$ & 875 & 6 & 825 \\
\hline II & 1975 & 10 & 1725 & -4 & 1800 \\
\hline 12 & 3388 & $35^{\star}$ & $313 I$ & $22^{\star}$ & 2570 \\
\hline 13 & 3500 & 8 & 3767 & $17^{\star}$ & 3233 \\
\hline 14 & 3500 & 0 & 3800 & 9 & 3500 \\
\hline 15 & 991 & $18^{\star}$ & 1350 & $60 *$ & 842 \\
\hline 16 & 1956 & $18^{\star}$ & 1913 & $15^{\star}$ & 1663 \\
\hline 17 & 3594 & $35^{\star}$ & 3600 & $35^{\star}$ & 2663 \\
\hline 18 & 925 & $2 I^{\star}$ & 916 & $20^{\star}$ & 766 \\
\hline 19 & 733 & 2 & 733 & 2 & 716 \\
\hline 20 & 4600 & -9 & 5043 & 0 & 5062 \\
\hline 21 & 2525 & 0 & 2350 & -6 & 2513 \\
\hline 22 & 1550 & -7 & 1303 & -22 & 1666 \\
\hline 23 & 1517 & I & 1583 & 5 & 1500 \\
\hline 24 & 2119 & 9 & 2275 & $18 \star$ & 1938 \\
\hline 25 & 925 & $16^{\star}$ & 675 & -16 & 800 \\
\hline 26 & 825 & -4 & 900 & 5 & 856 \\
\hline Mean & 2065 & II 4 & 2044 & $9 \cdot 3$ & I889 \\
\hline SEM & 215 & $4 \cdot 3$ & 221 & 3.9 & 205 \\
\hline $\begin{array}{l}P \text { values } \\
\text { by } W \text { ilcoxc }\end{array}$ & $\begin{array}{l}<0.05 \\
\text { matched-pairs s }\end{array}$ & $\begin{array}{l}<0.01 \\
\text { signed ranks text }\end{array}$ & $<0.05$ & $<0.05$ & \\
\hline \multicolumn{2}{|c|}{$\begin{array}{l}\text { Number of responders } \\
\text { Mean increase of responders }\end{array}$} & $\begin{array}{ll}\text { II } \\
28 \%\end{array}$ & & $\begin{array}{l}12 \\
26 \%\end{array}$ & \\
\hline
\end{tabular}

responders'. Thus 57 per cent of the 26 patients responded with at least a 26 per cent increase in exercise tolerance on the standard dose.

Stratification of patients into $\mathrm{MI}+$ and $\mathrm{MI}-$ patients showed that $M I+$ patients increased their exercise tolerance by an average of 12.5 per cent (propranolol) to 17.3 per cent (alprenolol), compared with 4.9 per cent (propranolol) to 3.5 per cent (alprenolol) for the MI - patients. These figures are significantly different for the two groups $(\mathrm{P}<0.05)$. Of the 15 responders, II were $\mathrm{MI}+$ and $4 \mathrm{MI}-$, whereas of the non-responders, 4 were $\mathrm{MI}+$ and 7 $\mathrm{MI}-(\mathrm{P}=0.10$ for difference in distribution by Fischer test).

Attack rate and glyceryl trinitrate consumption Twenty-two patients recorded attacks and/or glyceryl trinitrate consumption therapeutically, and the mean values for both active compounds and placebo were calculated with no statistically significant differences in either variable being noted on the average (Table 3). During the run-in period, though 18 of the 26 patients had more than 5 attacks and/or consumed more than 5 glyceryl trinitrate a week during the first 4 weeks, these decreased about 40 per cent towards the end of the run-in period (Table 4). In view of this, only half of the patients had sufficient numbers of attacks or tablets consumed to make an individual assessment meaningful. We have chosen the limit of 2.5 attacks and/or tablets consumed per week as the limit for assessability. It was then found that 14 of the 26 patients were assessable with regard to these two variables. There was no difference between the two active drugs; in some patients, alprenolol was more effective, in others propranolol was more so, and in about one-third they were equally effective. Nine of the 14 assessable patients had a decrease of 20 per cent or more in either the 
TABLE 3 Weekly attack rate and glyceryl trinitrate consumption on standard dose regimen: values are means of all completed 5-month periods of treatment

\begin{tabular}{|c|c|c|c|c|c|c|}
\hline \multirow[t]{2}{*}{ Case No. } & \multicolumn{2}{|c|}{ Alprenolol } & \multicolumn{2}{|c|}{ Propranolol } & \multicolumn{2}{|l|}{ Placebo } \\
\hline & $\begin{array}{l}\text { Attack } \\
\text { rate }\end{array}$ & $\begin{array}{l}\text { Glyc. trin. } \\
\text { consumpt. }\end{array}$ & $\begin{array}{l}\text { Attack } \\
\text { rate }\end{array}$ & $\begin{array}{l}\text { Glyc. trin. } \\
\text { consumpt. }\end{array}$ & $\begin{array}{l}\text { Attack } \\
\text { rate }\end{array}$ & $\begin{array}{l}\text { Glyc. trin. } \\
\text { consumpt. }\end{array}$ \\
\hline $\mathbf{I}$ & 4 & $I \cdot 3$ & $2 \cdot 9$ & $I \cdot 4$ & $2 \cdot 8$ & $2 \cdot 4$ \\
\hline 2 & $4 \cdot 8$ & 4 & 6 & $4 \cdot 2$ & $8 \cdot 4$ & $6 \cdot 1$ \\
\hline 3 & $2 \cdot 7$ & 2 & $2 \cdot 3$ & $1 \cdot 8$ & $3 \cdot 2$ & 2 \\
\hline 5 & 3.9 & $1 \cdot 6$ & $7 \cdot 3$ & $I \cdot 6$ & 5.9 & 0.5 \\
\hline 6 & 0.9 & 0.8 & 0.9 & 0.9 & $I \cdot 6$ & $1 \cdot 5$ \\
\hline 7 & $3 \cdot 3$ & 4 & 7 & 7 & $6 \cdot 3$ & 7 \\
\hline 9 & $I \cdot I$ & $\mathrm{I} \cdot \mathbf{2}$ & $I \cdot 4$ & I. 5 & $I \cdot 3$ & $\bar{I} \cdot \mathrm{Y}$ \\
\hline 10 & 9 & $19 \cdot 8$ & $7 \cdot 8$ & 17 & $5 \cdot 3$ & $11 \cdot 5$ \\
\hline II & I & $1 \cdot 5$ & 0.3 & 0.3 & 0 & 0 \\
\hline 12 & 0.4 & 0.4 & 0.6 & 0.8 & $I \cdot I$ & $I \cdot I$ \\
\hline 13 & 5 & $15 \cdot 8$ & $6 \cdot 7$ & 13.7 & 6.8 & $20 \cdot 6$ \\
\hline 14 & 0 & 0 & $1 \cdot 5$ & $I \cdot 5$ & 2 & 2 \\
\hline 15 & $20 \cdot 8$ & $20 \cdot 8$ & II 9 & II.9 & I9. I & $19 \cdot I$ \\
\hline 16 & $\mathrm{I} 2 \cdot \mathrm{I}$ & $12 \cdot I$ & $8 \cdot 7$ & $9 \cdot 3$ & $9 \cdot 8$ & 10.8 \\
\hline 18 & 0.2 & $2 \cdot 7$ & $0 \cdot I$ & $2 \cdot 5$ & 0.4 & 0.3 \\
\hline 19 & $7 \cdot I$ & 0.2 & $5 \cdot 3$ & 0.1 & $5 \cdot 3$ & $\mathrm{I} \cdot \mathrm{I}$ \\
\hline 21 & 0.8 & 0.4 & I & 0.2 & 0.7 & 0.7 \\
\hline 22 & $\mathrm{I} \cdot 8$ & 0.8 & I & I & $I \cdot 2$ & 0.8 \\
\hline 23 & 10.3 & $2 \cdot 9$ & $9 \cdot 4$ & $I \cdot 4$ & $12 \cdot 2$ & $12 \cdot 2$ \\
\hline 24 & $6 \cdot 4$ & $10 \cdot 2$ & $6 \cdot 3$ & $9 \cdot 4$ & $7 \cdot 7$ & $3 \cdot 2$ \\
\hline 25 & $2 \cdot 3$ & $2 \cdot 3$ & 0.5 & $1 \cdot 6$ & 3 & 2.5 \\
\hline 26 & $2 \cdot 2$ & 2 & 2.5 & 0.8 & 2.5 & 2.5 \\
\hline Means & $4 \cdot 60$ & $4 \cdot 80$ & $4 \cdot 15$ & $4 \cdot 15$ & 4.85 & 4.95 \\
\hline
\end{tabular}

Four patients (Cases 4, 8, 17, and 20) recorded no attacks or glyceryl trinitrate consumption after the run-in period, and have been excluded from this Table.

attack rate or the glyceryl trinitrate consumption or both on one of the beta blockers.

In order to analyse the seasonal variation of the glyceryl trinitrate consumption, we have taken all the figures for 16 patients who consumed at least 2.5 tablets per week during at least one month of the study. Figures from alprenolol and propranolol periods were included as there was no significant difference from placebo. The seasonal variation is very slight after the initial decrease. Low values for December 1969 and January 1970 may be due to the

TABIE 4 Gylceryl trinitrate consumption per week for the first 8 weeks, i.e. during the run-in period with placebo*

\begin{tabular}{lllll}
\hline Week & $I-2$ & $3-4$ & $5-6$ & $7-8$ \\
\hline Mean & $9 \cdot 3$ & $8 \cdot 1$ & $5 \cdot 4$ & $5 \cdot 5$ \\
SEM & $2 \cdot 4$ & $2 \cdot 1$ & $1 \cdot 4$ & $1 \cdot 4$
\end{tabular}

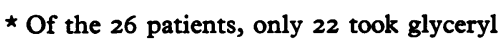
trinitrate for the attacks. For the other four patients, the number of attacks has been included in the calculations. fact that not all patients had entered the trial at that time. Later on there seems to be a slight decrease in the summer months, and an increase again toward the autumn.

Heart rate and blood pressure Calculations of the mean values showed that both active compounds produced a reduction in the resting heart rate, the rate recorded on completion of a standardized work load (i.e. $1200 \mathrm{kpm}$ ), and the rate on cessation of exercise; the effect of propranolol was more conspicuous. Systolic pressure at rest and on completion of $1200 \mathrm{kpm}$ was also reduced by both compounds, there being no statistically significant difference between alprenolol and propranolol (Table 5).

QT ratio Measurements of the $Q T$ ratio at the point of maximum exercise, when ischaemic changes in the heart would be most marked, showed a significant reduction with both compounds, when compared with placebo values (Table 6). At standard dose levels, the differences between placebo-alprenolol readings at rest, end of exercise, and at 2 minutes 
TABLE 5 Comparison of heart rates and systolic blood pressure measurements on standard and high dose schedules

\begin{tabular}{|c|c|c|c|c|c|c|c|c|c|}
\hline \multirow{2}{*}{ Heart rate } & & \multirow[t]{2}{*}{ Rest } & \multirow[t]{2}{*}{$S E M$} & \multicolumn{2}{|c|}{$\begin{array}{r}\text { At } 1200 \mathrm{kpm} \\
\text { SEM }\end{array}$} & \multicolumn{2}{|c|}{$\begin{array}{c}\text { End of exercise } \\
S E M\end{array}$} & \multicolumn{2}{|c|}{$\begin{array}{l}\text { Post-exercise } \\
2 \min 6 \min \end{array}$} \\
\hline & & & & & & & & & \\
\hline Standard dose & $\left\{\begin{array}{l}\text { Placebo } \\
\text { Alprenolol } \\
\text { Propranolol }\end{array}\right.$ & $\begin{array}{l}78 \\
67 \\
59\end{array}$ & $\begin{array}{l}I \cdot 47 \\
I \cdot 07 \\
I \cdot 08\end{array}$ & $\begin{array}{r}108 \\
95 \\
89\end{array}$ & $\begin{array}{l}2 \cdot 29 \\
2 \cdot 0 \\
1 \cdot 52\end{array}$ & $\begin{array}{r}121 \\
103 \\
95\end{array}$ & $\begin{array}{l}5 \cdot 21 \\
3 \cdot 22 \\
2 \cdot 86\end{array}$ & $\begin{array}{l}94 \\
78 \\
69\end{array}$ & $\begin{array}{l}83 \\
72 \\
63\end{array}$ \\
\hline High dose & $\left\{\begin{array}{l}\text { Placebo } \\
\text { Alprenolol } \\
\text { Propranolol }\end{array}\right.$ & $\begin{array}{l}75 \\
65 \\
53\end{array}$ & $\begin{array}{l}I \cdot 92 \\
I \cdot 14 \\
I \cdot I I\end{array}$ & $\begin{array}{r}106 \\
89 \\
81\end{array}$ & $\begin{array}{l}3 \cdot 36 \\
1 \cdot 75 \\
1 \cdot 81\end{array}$ & $\begin{array}{r}116 \\
95 \\
88\end{array}$ & $\begin{array}{l}9 \cdot 12 \\
2 \cdot 0 \\
2 \cdot 08\end{array}$ & $\begin{array}{l}90 \\
71 \\
60\end{array}$ & $\begin{array}{l}79 \\
69 \\
58\end{array}$ \\
\hline \multicolumn{10}{|c|}{ Systolic blood pressure } \\
\hline Standard dose & $\left\{\begin{array}{l}\text { Placebo } \\
\text { Alprenolol } \\
\text { Propranolol }\end{array}\right.$ & $\begin{array}{l}134 \\
130 \\
128\end{array}$ & $\begin{array}{l}2 \cdot 55 \\
2 \cdot 0 \\
2 \cdot 24\end{array}$ & $\begin{array}{l}\text { I55 } \\
\text { I47 } \\
\text { I46 }\end{array}$ & $\begin{array}{l}2 \cdot 95 \\
2 \cdot 95 \\
2 \cdot 81\end{array}$ & & & $\begin{array}{l}152 \\
146 \\
143\end{array}$ & $\begin{array}{l}135 \\
129 \\
128\end{array}$ \\
\hline High dose & $\left\{\begin{array}{l}\text { Placebo } \\
\text { Alprenolol } \\
\text { Propranolol }\end{array}\right.$ & $\begin{array}{l}135 \\
123 \\
122\end{array}$ & $\begin{array}{l}3.06 \\
2 \cdot 83 \\
2 \cdot 52\end{array}$ & $\begin{array}{l}150 \\
142 \\
139\end{array}$ & $\begin{array}{l}2 \cdot 63 \\
3 \cdot 30 \\
3 \cdot 49\end{array}$ & & & $\begin{array}{l}149 \\
143 \\
145\end{array}$ & $\begin{array}{l}134 \\
122 \\
128\end{array}$ \\
\hline
\end{tabular}

All heart rates on each dose level are significantly different from each other ( $p<0.0$ I or less). Blood pressure levels on each drug are significantly different from those on placebo $(p<0.025$ or less), but not between drugs.

and 6 minutes after exercise were all statistically significant. Differences between the two compounds only occurred at rest, with propranolol having a lower reading.

\section{TABLE 6 Comparison of $Q T$ ratio measurements}

\begin{tabular}{lllll}
\hline & Rest & $\begin{array}{l}\text { End of } \\
\text { exercise }\end{array}$ & $\begin{array}{l}2^{\prime} \text { post- } \\
\text { exercise }\end{array}$ & $\begin{array}{l}6^{\prime} \text { post- } \\
\text { exercise }\end{array}$ \\
\hline Standard dose study & & & \\
Placebo & 0.982 & 1.065 & 1.005 & 0.990 \\
Alprenolol & 0.938 & 1.027 & 0.968 & 0.951 \\
Propranolol & 0.924 & 1.022 & 0.967 & 0.944 \\
\hline
\end{tabular}

Differences between placebo-alprenolol, and placebo-propranolol are all statistically significant $(P<0.001)$

Differences between alprenolol-propranolol are only significant at rest $(\mathrm{P}<0.05)$

\begin{tabular}{|c|c|c|c|c|}
\hline \multicolumn{5}{|c|}{ Dose response study } \\
\hline $\begin{array}{l}\text { Placebo } \\
\text { Alprenolol } \\
\text { Propranolol }\end{array}$ & $\begin{array}{l}0.979 \\
0.973 \\
0.948\end{array}$ & $\begin{array}{l}\text { I.069 } \\
\text { I.037 } \\
\text { I.044 }\end{array}$ & $\begin{array}{l}\text { r.010 } \\
0.986 \\
0.974\end{array}$ & $\begin{array}{l}0.982 \\
0.967 \\
0.963\end{array}$ \\
\hline
\end{tabular}

Differences between placebo-alprenolol are statistically significant at end of exercise $(P<0 \cdot 00 \mathrm{I})$ and at $6^{\prime}$ post-exercise $(\mathbf{P}<0.05)$

Differences between placebo-propranolol are statistically significant at rest, end of exercise and $2^{\prime}$ post-exercise $(P<0.02)$ and at $6^{\prime}$ post-exercise $(P<0.05)$

Differences between alprenolol-propranolol only significant at rest $(\mathbf{P}<0.02)$
Triple product The triple product (TP) of heart rate, systolic blood pressure, and left ventricular ejection time is well correlated with myocardial oxygen consumption (Goldstein and Epstein, I972). We have calculated a triple product of heart rate, systolic blood pressure, and QT time for all treatment periods, based on the means of the heart rate, systolic blood pressure, and QT ratio for each individual treatment period. ${ }^{1}$ The values were all decreased on both drugs in comparison with placebo at rest, and at the end of exercise by 17 to 27 per cent (Table 7).

1 With Bazett's formula for the $\mathrm{QT}$ ratio, the equation can be written $\mathrm{TP}=3 \cdot \mathrm{I} \times \sqrt{\mathrm{HR}} \times \mathrm{BP} \times \mathrm{QT}$ ratio.

TABLE 7 Calculations of means of triple product of heart rate, systolic blood pressure, and $Q T$ ratio

\begin{tabular}{lrcc}
\hline & Rest & $\begin{array}{l}\text { End of } \\
\text { exercise }\end{array}$ & $\begin{array}{l}\% \text { reduction on com- } \\
\text { parison with placebo }\end{array}$ \\
\hline Standard dose only & & \\
Placebo & 1155 & 1829 & - \\
Alprenolol & 1000 & 1529 & 17 \\
Propranolol & 909 & 1445 & 21 \\
Dose response study & & \\
Placebo & $115 \mathrm{I}$ & 1733 & - \\
Alprenolol & 967 & 1323 & 25 \\
Propranolol & 846 & 1254 & 27 \\
\hline
\end{tabular}




\section{Dose response study}

By October 1970 when the dose response study started, only 18 of the 26 patients remained in the trial due to 4 withdrawals (2 myocardial infarctions, I death, I patient with side effects), I defaulter, and 3 others who had completed insufficient treatment periods on the standard dose regimen. On increasing the dose, one patient complained of drowsiness, and was withdrawn from this part of the study, though continued with the original standard dose regimen. Results of the remaining 17 patients are presented in Tables 8 to Io.

Total work There was a striking increase of between 35 and 47 per cent in exercise tolerance with an increased dose, which was statistically significant for both drugs. However, no significant difference was found between one and a half and two times the standard dose regimen (Table 8). The total work values have been shown for the first four 3-week periods (i.e. two periods on one and a half and two periods on two times the standard dose regimen), and for comparison all mean values for alprenolol and propranolol at standard dose, as well as placebo mean values.

There was no significant difference between the group who continued digoxin, and those who did not, nor between the two drugs (Tables 9 and 10). The apparent decrease on propranolol without digoxin was largely due to one patient (Case 24). It should also be noted in Table ro that owing to side effects at the highest dose level, the results on three of the patients (Cases I2, 13, and 17) were those for one and a half times the standard dose level. Case 23 was excluded from these calculations as he was unable to maintain higher dose levels due to the onset of hypotension and lassitude, and he returned to the standard dose regimen.

Stratification of the patients into $\mathrm{MI}+$ and $\mathrm{MI}-$ did not show any difference between these groups with regard to increase of the total work on increased dose.

Attack rate and glyceryl trinitrate consumption Results were assessable in 5 patients only, using previously mentioned criteria. The attack rate and/or tablet consumption differed by more than 20 per cent in 3 patients, all of whom had lower figures on propranolol.

Heart rate and blood pressure Both active compounds decreased these variables more than at

TABLE 8 Dose response study - total work performed (expressed in kpm) in initial four 3-week periods. For comparison, means of all placebo and active treatment periods from standard dose trial, for 17 patients, have been included

\begin{tabular}{|c|c|c|c|c|c|c|c|c|c|c|c|c|c|}
\hline \multirow{2}{*}{$\begin{array}{l}\text { Case } \\
\text { No. }\end{array}$} & \multirow{2}{*}{ Placebo } & \multicolumn{2}{|c|}{ Alprenolol } & \multicolumn{2}{|c|}{ Propranolol } & \multicolumn{2}{|c|}{ Alprenolol } & \multicolumn{2}{|c|}{ Propranolol } & \multicolumn{2}{|c|}{ Alprenolol } & \multicolumn{2}{|c|}{ Propranolol } \\
\hline & & $\begin{array}{l}400 \mathrm{mg} \\
\text { daily }\end{array}$ & $\%$ & $\begin{array}{l}\text { I60 mg } \\
\text { daily }\end{array}$ & $\%$ & $\begin{array}{l}600 \mathrm{mg} \\
\text { daily }\end{array}$ & $\%$ & $\begin{array}{l}240 \mathrm{mg} \\
\text { daily }\end{array}$ & $\%$ & $\begin{array}{l}800 \mathrm{mg} \\
\text { daily }\end{array}$ & $\%$ & $\begin{array}{l}320 \mathrm{mg} \\
\text { daily }\end{array}$ & $\%$ \\
\hline 5 & 2125 & 1200 & -44 & 1600 & -25 & 1200 & -44 & I950 & -8 & 1700 & -20 & 2050 & -4 \\
\hline 6 & 2563 & 3000 & I7 & 2950 & I5 & 3900 & 52 & 4200 & 64 & 3450 & 34 & 4200 & 64 \\
\hline 9 & 1219 & 1269 & 4 & 1594 & 30 & 1200 & -2 & 1800 & 48 & 1760 & 44 & 2325 & 92 \\
\hline I I & 1800 & 1975 & 9 & 1725 & -5 & 2250 & 25 & 2210 & 23 & 2250 & 25 & 2250 & 25 \\
\hline 12 & 2570 & 3388 & 31 & 3131 & 21 & 4800 & 37 & 3450 & 34 & & & & \\
\hline 13 & 3233 & 3500 & 8 & 3767 & I6 & 4700 & 45 & 3000 & -7 & 3800 & I8 & 3800 & I8 \\
\hline 15 & 842 & 991 & 17 & 1350 & 60 & 1200 & 43 & 1650 & 96 & 1425 & 69 & 1200 & 43 \\
\hline 16 & 1663 & 1956 & 17 & I9I3 & I5 & 2100 & 26 & 2145 & 29 & 2550 & 53 & 2100 & 26 \\
\hline 17 & 2663 & 3594 & 34 & 3600 & 35 & 5400 & 103 & 4200 & 58 & 3900 & 46 & 3700 & 39 \\
\hline I8 & 766 & 925 & 20 & 916 & 19 & 1200 & 57 & 1200 & 57 & I I 70 & 53 & 1200 & 57 \\
\hline 19 & 716 & 733 & 2 & 733 & 2 & 900 & 26 & 1050 & 47 & 1050 & 47 & 960 & 34 \\
\hline 21 & 2513 & 2525 & \pm 0 & 2550 & I & 2500 & $-\mathbf{I}$ & 3000 & 19 & 3550 & 41 & 3700 & 47 \\
\hline 23 & I500 & 1517 & I & 1583 & 5 & 1800 & 20 & 1650 & IO & & & & \\
\hline 24 & 1938 & 2119 & 9 & 2275 & 17 & 4250 & II9 & 3000 & 55 & 2950 & 52 & 5400 & I 79 \\
\hline 25 & 800 & 925 & 15 & 675 & -16 & 1525 & $9 I$ & I 125 & $4 I$ & 1200 & 50 & 1500 & 88 \\
\hline 26 & 856 & 825 & -4 & 900 & 5 & I050 & 23 & I050 & 23 & 750 & -12 & 930 & 9 \\
\hline Means & 1931 & $206 I$ & $7 \cdot 5$ & 2123 & I I·4 & $265 I^{\star}$ & 39.4 & $2475^{\star}$ & $35 \cdot 1$ & $2474^{\star}$ & $35 \cdot 5$ & $2667^{\star}$ & $47 \cdot 3$ \\
\hline SEM & 274 & 287 & $4 \cdot 3$ & 296 & $4 \cdot 8$ & 398 & 10.3 & 310 & 6.6 & $\begin{array}{c}355 \\
\mathrm{n}=15\end{array}$ & $6 \cdot 5$ & $\begin{array}{c}378 \\
n=15\end{array}$ & 12.0 \\
\hline
\end{tabular}

All drug means are significantly different from placebo with $\mathrm{P}<0.01$ or less.

* Significantly different from corresponding standard dose with $P<0.02$ or less.

There is no significant difference between the effects of one and a half times and twice the standard dose on either drug. 
TABLE 9 Calculations of total work performed (expressed in kpm) on twice the standard dose regimen (alprenolol $800 \mathrm{mg}$ daily, propranolol $320 \mathrm{mg}$ daily) for six 3-week periods: digitalis therapy withdrawn in last 4 periods

\begin{tabular}{|c|c|c|c|c|c|c|c|}
\hline \multirow[t]{2}{*}{ Case No. } & \multirow[t]{2}{*}{ Placebo } & \multicolumn{2}{|c|}{ With digitalis } & \multicolumn{4}{|c|}{ Without digitalis } \\
\hline & & Alprenolol & Propranolol & Alprenolol & Propranolol & Alprenolol & Propranolol \\
\hline 5 & 2125 & 1700 & 2050 & 1500 & 1650 & 1500 & 1650 \\
\hline II & 1800 & 2250 & 2250 & 2400 & 2250 & 3300 & 2325 \\
\hline 16 & 1663 & 2250 & 2100 & 2100 & 2325 & 2200 & 2100 \\
\hline 18 & 766 & 1170 & 1200 & 1600 & 1600 & 1500 & I500 \\
\hline 20 & 5062 & 5600 & 4700 & 5400 & 5250 & 5700 & 5400 \\
\hline $2 I$ & 2513 & 3550 & 3700 & 3400 & 3500 & 3150 & 2700 \\
\hline 24 & 1938 & 2950 & 5400 & 3000 & 2775 & 3300 & 2650 \\
\hline 25 & 800 & 1200 & 1500 & 1425 & 1000 & 1100 & 1500 \\
\hline Means & 2083 & 262 I & 2863 & 2603 & 2544 & 2719 & 2478 \\
\hline SEM & 477 & 517 & 547 & 473 & 472 & 528 & 451 \\
\hline \multirow{2}{*}{\multicolumn{2}{|c|}{$\begin{array}{c}\text { Percentage } \\
\text { increase }\end{array}$}} & & & & & & \\
\hline & & 26 & 38 & 26 & 22 & 30 & 19 \\
\hline
\end{tabular}

All drug means are significantly different from the placebo value with $\mathbf{P}<0.05$ or less.

There is no significant difference between alprenolol and propranolol with or without digoxin.

standard dose levels except for heart rate at rest on alprenolol (Table 5). It should be noted that at the end of exercise, high doses of alprenolol depressed the heart rate to about the same level as the standard dose of propranolol.

The rate of return to normal of the systolic blood pressure after work was different for the two betablockers. On alprenolol, the pre-exercise level was reached 6 minutes after exercise, whereas at that time on propranolol, systolic blood pressure was still significantly higher than before work $(P<0.02)$.
QT ratio This was slightly higher at the end of exercise for both beta-blockers when comparing the values on standard dose, but still significantly lower than on placebo. The rate of return to normal of the QT ratio after exercise was quicker on alprenolol where the value two minutes after exercise was almost the same as the resting value, whereas with propranolol the value at 6 minutes was still higher $(P<0.05)$.

Triple product This was decreased to about the same level as was found on the standard dose due

TABLE IO Dose response study - calculations of total work performed on twice standard dose regimen (alprenolol $800 \mathrm{mg}$ daily, propranolol $320 \mathrm{mg}$ daily) for six 3-week periods: digoxin therapy continued throughout

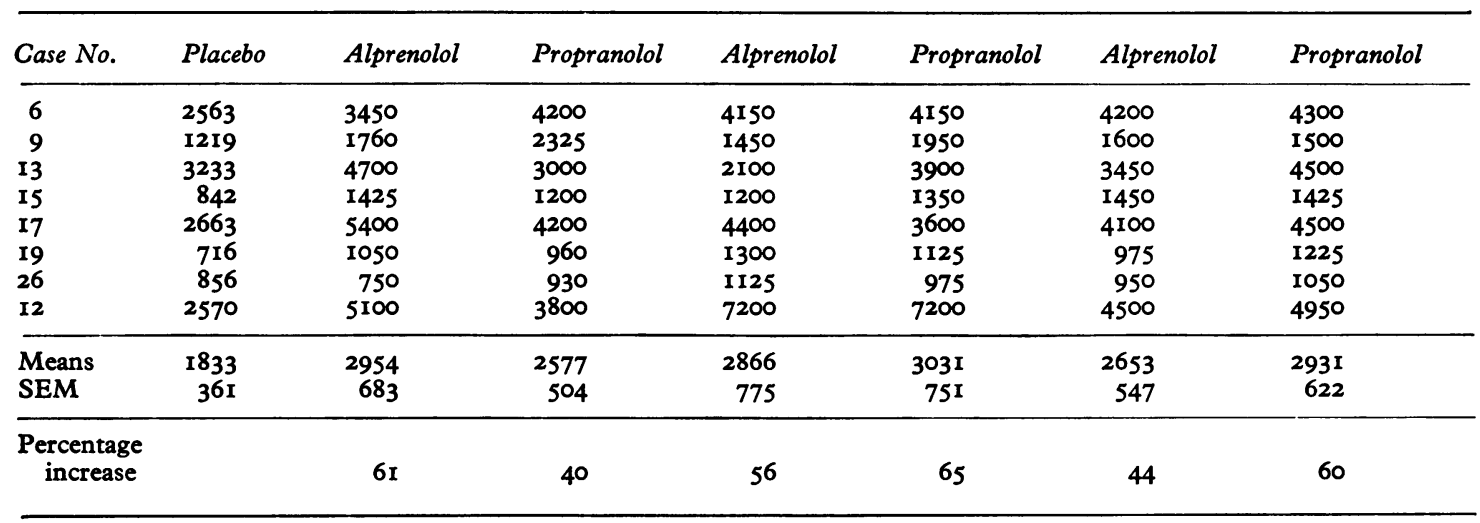

All drug means are significantly different from the placebo value with $P<0.05$ or less.

There is no significant difference between alprenolol and propranolol with or without digoxin. 
to the further decrease in heart rate and blood pressure being offset by the higher QT value compared with the standard dose results.

\section{Serum levels of alprenolol}

Variable levels were noted during the studies with a range in 46 samples of from 3 to $47 \mathrm{I} \mathrm{ng} / \mathrm{ml}$ (mean 6.2 ) during the $400 \mathrm{mg}$ daily dose regimen, in 19 samples of from 8 to $308 \mathrm{ng} / \mathrm{ml}$ (mean 7.8) at 600 $\mathrm{mg}$ daily, and in 32 samples of from 6 to $497 \mathrm{ng} / \mathrm{ml}$ (mean I I.8) at $800 \mathrm{mg}$ alprenolol daily. One patient (Case 2I) had exceptionally high serum levels on $400 \mathrm{mg}$ daily (220 to $479 \mathrm{ng} / \mathrm{ml}$ in 4 samples).

\section{Drop-outs, complications, and side effects}

During the entire 20 months of this study, only 4 patients complained of marked side effects, or suffered severe complications, necessitating their withdrawal from the trial (Table II). One female patient complained of swollen and painful hands and feet, with fever, during one of the alprenolol and one of the propranolol treatment periods. The symptoms subsided 48 to 72 hours after stopping the drug. These episodes occurred during the 7 th and I2th months of the study, and the patient had also complained of headaches during two of the placebo periods. Two patients were withdrawn

TABLE I I Summary of side effects, drop-outs, and complications

Number of patients entering the study (September I 969 to September 1970)

Defaulted for non-medical reasons

Withdrawn due to deterioration in run-in (placebo) period

Withdrawn due to sudden death

Withdrawn due to headaches on digoxin in run-in period

Remaining patients to complete at least one 3-month period of treatment in standard dose trial

Defaulted for non-medical reasons (after at least one 3-month period on standard treatment)

Withdrawn due to myocardial infarction

Withdrawn due to sudden death

Withdrawn due to swollen joints (see text)

Not completed standard dose programme by October I970

Remaining patients for dose-response study (October I970)

Withdrawn in first period due to drowsiness

Patients with side effects in dose-response study after at least two treatment periods, necessitating reduction of dose to one and a half times standard dose or standard dose$$
\text { I }
$$

when they suffered a further myocardial infarction (one during alprenolol and one during propranolol treatment). One death occurred in a male patient during the 12th month of treatment while on alprenolol; this as well as one death in the run-in period were considered to be due to the normal course of the disease.

The side effects and complications in the standard dose study are given in Table 12. The overall incidence was I per 12 treatment periods for alprenolol, I per 13.7 treatment periods for propranolol, and I per 6 treatment periods for placebo. The side effects that did not cause withdrawal from the study were varied, transient, and in no case interfered with the patient's normal daily progress, nor necessitated any changes in therapy. Fifteen of the patients did not complain of any side effects at all.

Of the 17 patients in the dose response study, 2 had to reduce the dose immediately from twice to one and a half the standard dose on account of either dyspnoea or blurred vision (Cases 12 and 17 ). Two other patients (Cases 13 and 23) were unable to sustain the higher dosage and had to reduce after a 12week period from twice to one and a half, and from one and a half to standard dose respectively, due to the onset of normotensive dizziness, or lassitude associated with hypotension.

\section{Laboratory investigations and patient's weight}

The analysis of the screening investigations showed no pathological variation during the course of the study. Average weights remained about the same on all three treatments.

TABLE I2 Side effects and complications reported in standard dose study

I

3 Insomnia

I8 Dizziness

I8 Lassitude

I

Palpitations

No. of side effects

No. of treatment periods 84

7
84

6

82

19 


\section{Discussion}

The present study confirms the efficacy of the adrenergic beta-receptor blocking drugs in the treatment of angina pectoris. Previous studies with alprenolol have shown an increased exercise tolerance of between 20 and 60 per cent after an oral $100 \mathrm{mg}$ dose (Adolfsson, Areskog, and Rasmuson, 197I; Sealey et al., 1970, 1971 ; Dagenais, Pitt, and Ross, I971; Sowton and Smithen, 1971: Fritz-Hansen, Rasmussen, and Nyberg, 1973; Keyriläinen, $\mathrm{Ny}-$ berg, and Uusitalo, 1973). Similar findings were reported with propranolol after a $40 \mathrm{mg}$ dose orally (Gianelly et al., 1967; Battock, Alvarez, and Chidsey, 1969).

The lower figure of around a Io per cent increase in this study may be due to the long-term treatment period (average of 17 months per patient) set against the background of the normal course of the disease. A further explanation may be found in the varying methodology of different investigators. Total work performed may vary depending on whether a single load, or stepwise increases are used. Redwood et al. (I97I) suggested that it was better to start below the critical load, and increase it after a few minutes. However, the time on each load should not be too long as this might result in changes caused by prolonged exercise after Io to 15 minutes (Ekelund, r967).

Accepting a 15 per cent increase in exercise tolerance over placebo values as an indication of response, there were II alprenolol and I2 propranolol 'responders'. The mean increases in exercise tolerance in these two treatment groups were 28 and 26 per cent, respectively. Those of the responders who continued with the dose response study (9 patients) showed a further increase of at least as much as that reached on the standard dose on either or both drugs in practically all cases. Of the 7 non-responders who continued with the dose response study, 6 also showed a significant increase in exercise tolerance. This confirms that the optimum dose is quite often higher than the one chosen from the start of the study as the standard dose.

The improvement in exercise tolerance of between 35 and 47 per cent in the dose response study confirmed the finding of Sandler (1971) and other investigators (J. Hoy and E. Sowton, 1970, unpublished data) that the effects of increasing the dose of one beta-blocker are unlikely to follow the same patterns as increasing the dose of another. However, in our findings, the differences in the results of the groups at one and a half and twice the standard dose levels were not statistically significant. Sealey et al. (1970) showed an average increase in total work of 32 per cent after alprenolol $100 \mathrm{mg}$ but only a 25 per cent increase after $200 \mathrm{mg}$. In some of his patients, the obvious decrease in exercise tolerance on the higher dose was probably due to a fall in blood pressure towards the end of exercise, resulting in a fall in the coronary perfusion pressure, or a lowered perfusion pressure in the legs, whereas in others (3 out of (o), exercise tolerance increased clearly without a concomitant obvious reduction in blood pressure, as in the present trial.

The results during the run-in period of an 'overshoot' of about 20 per cent in the second to the fourth tests supported both Sealey's findings (1970) of the necessity for repeated tests to eliminate the 'rapport' period response, and also the recommendation of Redwood et al. (I97I) that several test periods should be employed to enable patients to become accustomed to the bicycle exercise technique.

In the exercise tests, we have chosen as the end point the onset of that degree of pain which would, under normal circumstances, force that patient to discontinue his activity. It has been stressed that deliberate exercise to this point could be considered dangerous and non-ethical. We are of the opinion that if a patient exerts himself to that degree of pain in his home, it is safe for him to repeat this under hospital conditions with continuous monitoring, and where resuscitation facilities are to hand if required. Furthermore, it is very difficult to decide the exact onset of vague discomfort during exercise preceding actual pain. Though slightly more than half of the patients studied complained of pain at the end point during exercise, 7 complained of acute dyspnoea throughout the trial. There was no significant difference in total work increase between patients with pain at the end point and those with dyspnoea. It was felt that this breathlessness was due to acute left ventricular failure, and that the rapid disappearance of symptoms after stopping exercise was accompanied by a rapid return to normal of left ventricular function (Sharma and Taylor, 1970).

Other workers (Taylor, I97I) have recommended digitalis before beta-blockade for patients with angina associated with congestive cardiac failure, because of the combined effectiveness. However, in the group of 8 patients in the dose response study where digitalis was withdrawn, the apparent decrease in exercise tolerance on the highest dose of propranolol was due largely to one patient, and was not statistically significant. Though Smith, Bousvaros, and McGregor (1966) in a double-blind study on 15 anginal subjects failed to show any obvious influence of digitalis on exercise tolerance in angina pectoris patients, it could well be only beneficial to those patients with some degree of cardiomegaly. In the absence of heart failure, Parker et al. (1969) 
were unable to find any evidence of significant clinical or haemodynamic benefit from digitalis in exertional angina. Their findings were in contrast to those of Malmborg (1965) who reported that digitalis therapy was of value in approximately 50 pet cent of patients with coronary artery disease, even when clinical signs of congestive failure were lacking. In this latter study, patients were exercised in the supine position, which in terms of haemodynamic consequences is probably quite different from exercise in the sitting position.

Our findings in the attack rate and the glyceryl trinitrate consumption confirm the impressions of other authors (Sharma et al., 1971; Sowton and Smithen, I97I) that such measurements for the quantitative assessment of anginal therapy are useless. The only possible exception may be those patients who experience many attacks of angina every day (Riseman, 1966).

Pentecost, George, and Nagle (I97I) have pointed out a major pitfall in the assessment of therapy in prescribing a fixed dose for all patients. They suggested an initial run-in period of at least 6 weeks, followed by a dose response study based on the subjective comments of the patients themselves in regard to an improvement in their angina. We do not accept that this subjective assessment is valid in those patients in whom the attack rate and/or glyceryl trinitrate consumption may be low and thus of little value in helping the patient to determine his own status. Furthermore, improvement in exercise with increasing doses may not be accurately noted by the patient. A comparison of the objective measurement of exercise tolerance gives a more reliable guide to the therapeutic effect. We agree with Sandler (197I) that an exercise tolerance test with electrocardiographic control is the simplest method of studying antianginal drugs in patients with relatively infrequent attacks.

The mechanism of action of adrenergic betablockers in angina has been well shown. The triple product at the end of exercise was decreased in the present study by both compounds at equipotent doses to about the same degree, in comparison with placebo. However, if the imbalance between oxygen demand and supply at the point of angina is assumed to be the same, one would expect the same triple product after beta-blockade at cessation of work. The fact that it was lower after beta-blockade, which Robinson (1967) also found using the simple product of heart rate and blood pressure, indicated that the oxygen sparing effect of the reduced external load on the heart was offset by another effect of the beta-blockers which tended to increase oxygen consumption. One such factor may be the heart size. The importance of the relation of heart size to myo- cardial oxygen consumption was confirmed by the results of Dagenais et al. (1971) who found that under the influence of nitrates, there was an increase in exercise tolerance without a decrease in the heart rate - blood pressure product at the point of angina. Nitrates are known to decrease heart size.

Contrary to widespread belief, there was no difference in the average resting heart rates on placebo of the exercise responders and non-responders. The beta-blocking effects of both alprenolol and propranolol were seen in the significant reduction of heart rate when compared with placebo values, both at rest, at $1200 \mathrm{kpm}$, and at the end of exercise. Though the absolute values were lower with propranolol, it should be noted that the heart rate increase from rest to the end of exercise was reduced to the same degree ( $16 \%$ ) by both drugs on standard doses, and more by alprenolol (27\%) than by propranolol $(15 \%)$ at higher dose levels due to the resting heart rate not being further depressed by the higher dose of alprenolol (Table ro). This bears out the absence of intrinsic beta-stimulating effect of propranolol in contrast to alprenolol, and is not due to incomplete blockade ( $\AA$ blad et al., 1971).

In the electrocardiographic evaluation of angina, measurement of the ST segment depression has usually been used as an index of myocardial ischaemia. However, digitalis is known to give false positive results (Kawai and Hultgren, 1964) and, therefore, the QT ratio was estimated instead. It is accepted that healthy subjects react to exercise with a shortening of the QT ratio with or without digoxin, while patients with ischaemic heart disease develop a lengthening of the QT ratio with exercise (Frankl, Deitz, and Soloff, I968). Decrease of the QT ratio can be interpreted as evidence of lessened myocardial ischaemia, possibly due to an improved balance between oxygen delivery and demand by the heart. Though it is accepted that levels of $\mathrm{I} \cdot 08$ or more indicate ischaemic heart disease (Master and Rosenfeld, I96I), the absolute value may be less important than the actual increase during exercise (Frankl et al., I968). In this study, the QT ratio increased as expected, but only to approximately I.07 on placebo. On both active compounds, it was significantly lower, both at standard dose and high dose levels (Table 5). On this basis, it appears that there was less ischaemic change during exercise with alprenolol and propranolol than with placebo. Furthermore, the normalization time was more rapid with alprenolol than propranolol. It was interesting to note that the same difference of normalization occurred in the systolic blood pressure after effort on the higher doses.

In repeated serum alprenolol level estimations, an increase in the mean levels occurred as the daily dose 
was raised, but there was considerable individual variation which supports similar findings of other authors (Sowton and Smithen, 1971). There was no correlation between the therapeutic effect and serum levels in individual cases, and it appeared impossible to predict with reasonable accuracy the individual degree of beta-blockade for a set serum level.

This trial has shown that both compounds are equally effective (at doses with equal beta-receptor inhibitory effect) in increasing exercise tolerance at all three dose levels, with about 60 per cent of the patients responding noticeably on the standard dose levels, increasing to about 90 per cent when the dose is increased by one and a half or twice. With increasing dosage, a larger increase in exercise capacity was also found in those patients who had responded favourably at standard dose levels. Though further side effects occurred at higherdose levels in some cases, they affected only the minority, and all patients were able to continue treatment with one step down in the dose, maintaining improved exercise tolerance.

An unexpected finding was that patients with a previous myocardial infarction respond better at standard dose levels than those who have not had an infarction.

Neither drug turned out to be more cardiodepressant than the other, but possible differences might have been masked by digitalization. Though alprenolol, in equipotent dosages, caused less decrease of the heart rate during work than propranolol, it was not less efficacious.

The authors gratefully acknowledge the help, cooperation, and encouragement of the Staffs of the Department of Cardiology at the Royal Free Hospital, London N.W.3; St. Mary's Hospital, London W.2; The Whittington Hospital, London N.19; and Willesden General Hospital, London N.W.10.

We also wish to thank Astra Chemicals Ltd. for the supply of clinical trial materials, Mr. Magnar Ervik for his assistance with the chemical assay of alprenolol in serum, and Miss Kerstin Rutgersson for skilful secretarial support and assistance in the statistical calculations.

\section{References}

Åblad, B., Brändström, A., Ek, L., and Sjölander, M. (1971). Analysis of the actions of alprenolol and propranolol on the beta adrenergic receptors controlling heart rate in the anaesthetized cat. European Fournal of Pharmacology, 14, 319.

Åblad, B., Johnsson, G., Norrby, A., and Sölvell, L. (1967). Potency and time-effect relationship in man of propranolol and $\mathrm{H}_{56 / 28}$ - comparative studies after oral administration. Acta Pharmacologica et Toxicologica, 25, Suppl. 2, p. 85 .

Adolfsson, L., Areskog, N. H., and Rasmuson, T. (I97I). Effects of alprenolol and isosorbide dinitrate during exer- cise in patients with coronary insufficiency. European fournal of Clinical Pharmacology, 3, 68.

Battock, D. J., Alvarez, H., and Chidsey, C. A. (1969). Effects of propranolol and isosorbide dinitrate on exercise performance and adrenergic activity in patients with angina pectoris. Circulation, 39, 157.

Bazett, H. C. (1920). Analysis of the time-relations of electrocardiograms. Heart, 7, 353.

Dagenais, G. R., Pitt, B., and Ross, R. S. (197I). Exercise tolerance in patients with angina pectoris. American fournal of Cardiology, 28, 10.

Ekelund, L. G. (1967). Circulatory and respiratory adaptation during prolonged exercise. Acta Physiologica Scandinavica, 70, Suppl. 292.

Ervik, M. (1969). Gas chromatographic determination of the secondary amine alprenolol, as its trifluoroacetyl derivative, at nanogram levels in biological fluids. Acta Pharmaceutica Suecica, 6, 393.

Frankl, W. S., Deitz, R. D., and Soloff, L. (1968). The QT ratio as a guide to the exercise test in the digitalized subject. Diseases of the Chest, 54, I 19.

Fritz-Hansen, P., Rasmussen, P. A., and Nyberg, G. (1973). Alprenolol alone and in conjunction with pentanitrol in angina pectoris. A double blind study with exercise tests. Acta Medica Scandinavica. In the press.

Gianelly, R. E., Goldman, R. H., Treister, B., and Harrison, D. C. (1967). Propranolol in patients with angina pectoris. Annals of Internal Medicine, 67, 1216.

Goldstein, R. E., and Epstein, S. E. (1972). Medical management of patients with angina pectoris. Progress in Cardiovascular Diseases, 14, 360.

Kaltenbach, M., et al. (I97I). Comparable doses of different beta-blockers in man, their effects on haemodynamics, heart rate, peripheral blood flow, heart size, bronchial resistance and angina pectoris. In Coronary Heart Disease, International Symposium in Frankfurt, p. 196. Ed. by M. Kaltenbach and P. Lichtlen. Goerg Thieme, Stuttgart.

Kawai, C., and Hultgren, H. N. (1964). The effect of digitalis upon the exercise electrocardiogram. American Heart fournal, 68, 409.

Keyriläinen, O., Nyberg, G., and Uusitalo, A. J. (1973). The effects of alprenolol and isosorbide dinitrate in angina pectoris. Acta Medica Scandinavica. In the press.

Malmborg, R. O. (1965). A clinical and haemodynamic analysis of factors limiting the cardiac performance in patients with coronary heart disease. Acta Medica Scandinavica, I77, Suppl. 426, 6.

Master, A. M., and Rosenfeld, I. (I96I). Criteria for the clinical application of the 'two step' exercise test. fournal of the American Medical Association, 178, 283.

Parker, J. O., West, R. O., Ledwich, J. R., and Di Giorgi, S. (1969). The effect of acute digitalization on the hemodynamic response to exercise in coronary artery disease. Circulation, 40, 453.

Pentecost, B. L., George, C. F., and Nagle, R. E. (I97I). Assessment of drugs in angina pectoris. Postgraduate Medical fournal, 47, Suppl. 48.

Redwood, D. R., Rosing, D. R., Goldstein, R. E., Beiser, G. D., and Epstein, S. E. (1971). Importance of the design of an exercise protocol in the evaluation of patients with angina pectoris. Circulation, 43,618 .

Riseman, J. E. F. (1966). The clinical course of angina pectoris. American fournal of the Medical Sciences, 252, 146.

Robinson, B. F. (1967). Relation of heart rate and systolic blood pressure to the onset of pain in angina pectoris. Circulation, 35, 1073.

Sandler, G. (1971). Assessment of drugs in angina pectoris. Postgraduate Medical fournal, 47, Suppl. 50. 
Sealey, B. J., Liliedal, J., Nyberg, G., and Åblad, B. (1970). Effects of alprenolol in various doses, orally and intravenously, on exercise tolerance in angina pectoris patients. Presentation at the Annual Meeting of the Swedish Society for International Medicine in Stockholm. November 26.

Sealey, B. J., Liljedal, J., Nyberg, G., and Åblad, B. (1971). Acute effects of oral alprenolol on exercise tolerance in patients with angina pectoris. British Heart fournal, 33, 481.

Sharma, B., Meeran, M. K., Galvin, M. C., Tulpule, A. T., Whitaker, W., and Taylor, S. H. (197I). Comparison of adrenergic beta-blocking drugs in angina pectoris. British Medical fournal, 3, 152.

Sharma, B., and Taylor, S. H. (1970). Reversible left-ventricular failure in angina pectoris. Lancet, 2, 902.
Smith, H. J., Bousvaros, G. A., and McGregor, M. (1966). Failure of acute digitalization to influence exercise tolerance in angina pectoris. British Medical fournal, $1,1337$. Sowton, E., and Smithen, C. (I97I). Double-blind three-dose trial of oral alprenolol in angina pectoris. British Heart fournal, 33, 601.

Taylor, S. H. (197I). Angina pectoris (letter). British Medical fournal, 2, 713.

Request for reprints to Dr. Edwin Besterman, Department of Cardiology, St. Mary's Hospital, Praed Street, London W2 INY. 